\title{
Primary potassic magmatism produced from amphibole-clinopyroxene- apatite-rich mantle source in the São Francisco Craton, Brazil, and the key role of mantle heterogeneity in the diversity of alkaline magmatism
}

\author{
Jorge Plá Cid ${ }^{1,2,5}$, Basílio Elesbão da Cruz Filho ${ }^{2}$, Herbet Conceição' ${ }^{2}$, Débora Correia Rios ${ }^{1,2}$, \\ Maria de Lourdes da S. Rosa ${ }^{2,3}$ \& Henrique Matos da Rocha ${ }^{1}$
}

\begin{abstract}
The Gameleira meladiorites are represented by dykes and mafic microgranular enclaves associated to the shoshonitic Gameleira monzonite. Dykes are a few centimeters wide and have well-defined contacts with the host monzonite. This association belongs to the Paleoproterozoic alkaline magmatism from Serrinha nucleus, northeast Brazil. The near-liquidus paragenesis is represented by clinopyroxene, amphibole, apatite and mica, while feldspars are restricted to interstitial grains. Chemical analyses show low-silica rocks, with an alkaline character defined by $\mathrm{Na}_{2} \mathrm{O}+\mathrm{K}_{2} \mathrm{O}$ contents above $3 \mathrm{wt} \%$, and a potassic signature $\left(\mathrm{K}_{2} \mathrm{O} / \mathrm{Na}_{2} \mathrm{O} \approx 2\right)$. High $\mathrm{MgO}$ and $\mathrm{Cr}$ concentrations are consistent with a primary liquid, and concentrations of these elements, as well as Al, K, P, Ba, Ni, and light rare earth elements are consistent with an olivine-free metasomatic mantle source enriched in amphibole, clinopyroxene and apatite. In contrast, the ultrapotassic lamprophyres associated to the contemporaneous magmatism Morro do Afonso were probably produced by melting of a clinopyroxenephlogopite-apatite enriched-source. The identification of different mineral paragenesis in the source of ultrapotassic lamprophyres and potassic meladiorites from Serrinha Nucleus can aid to better understand the tectonic evolution of this region.
\end{abstract}

Keywords: potassic magmatism, Serrinha Nucleus, mantle metasomatism.

\begin{abstract}
Resumo Magmatismo potássico primário produzido por fonte mantélica rica em anfibólio-clinopiroxênio-apatita no Cráton do São Francisco, Brasil, e o papel chave da heterogeneidade mantélica na diversidade do magmatismo alcalino. Os meladioritos do Maciço Monzonítico de Gameleira, de natureza shoshonítica, ocorrem como diques e enclaves microgranulares máficos. Os diques constituem corpos com poucos centímetros de espessura que apresentam contatos bem definidos com os monzonitos encaixantes. Associação similar é comum em outros maciços alcalinos paleoproterozóicos do Núcleo Serrinha. A paragênese liquidus é representada por clinopiroxênio, anfibólio, apatita e mica. Cristais de feldspato ocorrem restritos aos interstícios. As rochas máficas apresentam composição com baixos conteúdos em sílica, possuem caráter alcalino bem definido, com conteúdo de $\mathrm{Na}_{2} \mathrm{O}+\mathrm{K}_{2} \mathrm{O}$ superior a $3 \%$ e assinatura potássica $\left(\mathrm{K}_{2} \mathrm{O} / \mathrm{Na}_{2} \mathrm{O} \approx 2\right)$. As altas concentrações em $\mathrm{MgO}$ e $\mathrm{Cr}$ são compatíveis com líquido de natureza primária e as concentrações de elementos como $\mathrm{Al}, \mathrm{K}, \mathrm{P}, \mathrm{Ba}$ e Ni, assim como os conteúdos dos ETR são compatíveis com gênese a partir de fusão de fonte mantélica metassomatizada e enriquecida em anfibólio, clinopiroxênio e apatita. Por outro lado, é adimitida uma fonte rica em clinopiroxênio, flogopita e apatita para a gênese do magmatismo lamprofírico ultrapotássico contemporâneo presente no Maciço Sienítico Morro do Afonso. A identificação de diferentes paragêneses da fonte responsável pela geração de lamprófiros ultrapotássicos e meladioritos potássicos no Núcleo Serrinha constitui uma indicação importante para auxiliar a compreensão da evolução geotectônica desta região.
\end{abstract}

Palavras-chave: magmatismo potássico, Núcleo Serrinha, metassomatismo mantélico.

INTRODUCTION Alkaline magmatism is frequent in within-plate settings (Whalen et al. 1987, Bonin 1996), associated to extensional processes, where it chemically exhibits elevated concentrations of High Field Strength Elements (HFSE) in opposition to moderate and low amounts of Large Ion Lithophiles (LIL). This sort of alkaline magmas defined the usual concept of the alkaline series and their evolution (Lameyre \& Bowden 1982). In Bahia, northeast Brazil, examples of within-plate magmatism in the Paleoproterozoic are the Angico dos

1 - PRODOC-FAPESB, Instituto de Geociências, Universidade Federal da Bahia, Salvador (BA), Brasil. E-mail: jorge.pla@bol.com.br

2 - Laboratório de Petrologia Aplicada à Pesquisa Mineral (GPA), Centro de Pesquisa em Geofísica e Geologia - IGEO-UFBA, Salvador (BA), Brasil. E-mail: herbet@ufba.br, debora@cpgg.ufba.br, lourdes@cpgg.ufba.br

3 - Pesquisadora PRODOC-CAPES-UFBA, Salvador (BA), Brasil.

4 - Bolsista de Iniciação Científica PIBIC-UFBA, Salvador (BA), Brasil.

5 - Departamento Nacional de Produção Mineral - DNPM/SC. 
Dias carbonatites (Silva 1987) and alkaline and peralkaline granites from Campo Alegre de Lourdes (Plá Cid et al. 2000), and in the Neoproterozoic, the southernmost occurrences of undersaturated and saturated syenitic province (PASEBA; Rosa et al. 2000). During the last twenty years numerous occurrences of alkaline rocks in present and ancient subduction-related settings have been studied (Thompson \& Fowler 1986, Leat et al. 1988, Ringwood 1990, Corriveau \& Gorton 1993, and references therein). Compared to the within-plate, anorogenic and post-orogenic alkaline rocks, subduction-related alkaline magmas are depleted in HFSE and show extreme enrichments in LILE and Light Rare Earth Elements (LREE), which has been interpreted by several authors as related to a mantle source previously modified by dehydration-melting from subducted-slab. In this sense, arc-related magmas characteristically are potassic, against sodium dominant character of withinplate magmas, identified as belonging to shoshonitic and potassic-ultrapotassic series. This paper deals with potassic primary magmas, with arc-affinity, in the $\mathrm{Pa}$ leoproterozoic of northeast Brazil, and its probable Archaean-modified source.

REGIONAL FRAMEWORK The São Francisco craton (SFC) is a crustal segment of the South American Plataform stabilized in the Paleoproterozoic $(1.8 \mathrm{Ga})$, limited by Neoproterozoic $(0.6 \mathrm{Ga})$ reworked terrains. Internally, the SFC is segmented in three Archaean nuclei: Guanambi, Remanso and Serrinha (SerN) from west to east, which are separated by NS-trending Paleoproterozoic fold belts formed by collisional events between these nuclei (Mascarenhas 1979). The studied area is located in the SN (Fig. 1).

The main lithologies of the SerN comprise: (i) an Archaean gneissic basement; (ii) Archaean calcalkaline TTG association; (iii) Paleoproterozoic volcanicsedimentary Rio Itapicuru Greenstone Belt (RIGB); (iv) Paleoproterozoic calc-alkaline rocks and TTG; (v) Paleoproterozoic alkaline magmatism. The Paleoproterozoic calc-alkaline magmatism $(2.13-2.16$ $\mathrm{Ga})$ shows juvenile $\mathrm{Sm}-\mathrm{Nd} \mathrm{T}_{\mathrm{DM}}$ ages $(2.18-2.33 \mathrm{Ga})$, whereas the presence of Archaean TTG associations indicates an older subduction event. In this same way, the Paleoproterozoic $(2.08-2.10 \mathrm{Ga})$ alkaline magmatism produced Archaean Sm-Nd $\mathrm{T}_{\mathrm{DM}}$ ages (2.58 - 2.96 $\mathrm{Ga}$ ), and its subduction-related signatures confirms the Archaean subduction-related setting. For more isotopic data and detailed discussion, see Rios (2002).

The alkaline magmatism comprises shoshonitic batholiths (e.g. Itareru massif) and ultrapotassic syenites and lamprophyres (e.g. Morro do Afonso Massif, Rios 2002). The studied area is located a few kilometers to the west of the Morro do Afonso Massif (Fig. 1) and is formed by the Gameleira massif, monzonitic in composition and with shoshonitic affinity (based on unpublished chemical data). The magmatism here presented is formed by mafic dykes, intrusive in the Gameleira monzonites and quartz-monzonites, and mafic microgranular enclaves mingled with these monzonitic rocks. The host rock is medium to coarse grained constituted by plagioclase and alkali feldspar phenocrysts, as well as amphibole, in a groundmass of same minerals. Rare mica crystals were observed; titanite is the main accessory phase, with few amounts of apatite. No metamorphic textures were observed, and the internal crystal orientation is exclusively due to the magma flow. The genetic relation between the monzonite and the mafic magma is possible, but this will not be discussed in this paper. Until the present no isotopic data were available for these rocks, although the field relations and geochemical patterns of this intrusion are similar to the ones of Paleoproterozoic alkaline magmatism on this region.

The main aim of this paper is to characterize the mafic magmatism associated to the Gameleira monzonite, since it represents a primary magma derived from a metasomatic mantle-source. A comparison with the contemporaneous Morro do Afonso ultrapotassic lamprophyres (Rios 2002, Plá Cid et al. 2006) points to the mantle heterogeneity promoted by ocean-plate dehydration, and the different alkaline primary magmas derived from melting of these sources.

FIELD AND PETROGRAPHIC FEATURES The alkaline mafic magmatism occurs as dykes and enclaves, locally microgranular, contemporaneous to the Gameleira shoshonitic monzonite. Enclaves have elliptical or irregular shapes, are up to $10 \mathrm{~m}$ wide, show sinuous contacts with the host monzonite, and internal flow structures. They are very fine-grained rocks aligned parallel to the magmatic foliation of the monzonite, and frequently hybridized as attested by feldspars xenocrysts of the host rock.

The better preserved examples of this magmatism are represented by dykes, which intrude the monzonite with straight and non reactive contacts. These dykes are tabular intrusions, less than $0.5 \mathrm{~m}$ wide and more than $50 \mathrm{~m}$ long. These rocks are mafic, fine to medium grained, with black and dark green color.

The petrography of the Gameleira dykes reveals amounts around $80 \%$ of mafic minerals. Dykes are inequigranular oriented rocks, with euhedral amphibole crystals aligned by magmatic flow. Deep-green and -brown amphiboles are the dominant mafic-phases. Included in amphiboles were observed colorless clinopyroxene grains, which are also oriented by the magmatic flow, and euhedral apatite and mica. The paragenesis clinopyroxene-apatite-mica constitutes the near-liqui$d u s$ assemblage. Subhedral yellowish allanite grains are included in amphibole, interpreted also as a near-liqui$d u s$ mineral, pointing to a rare earth elements (REE) enriched liquid. Titanite occurs as anhedral crystals included in amphibole, with sinuous contacts suggesting late-magmatic, low-temperature, exsolution from amphibole. Felsic minerals are interstitial, consisting of plagioclase and homogeneous alkali feldspar grains. According to the modal proportions, these rocks can be petrographically classified as melanocratic diorites. The presence of typical hydrous phases, as mica, am- 


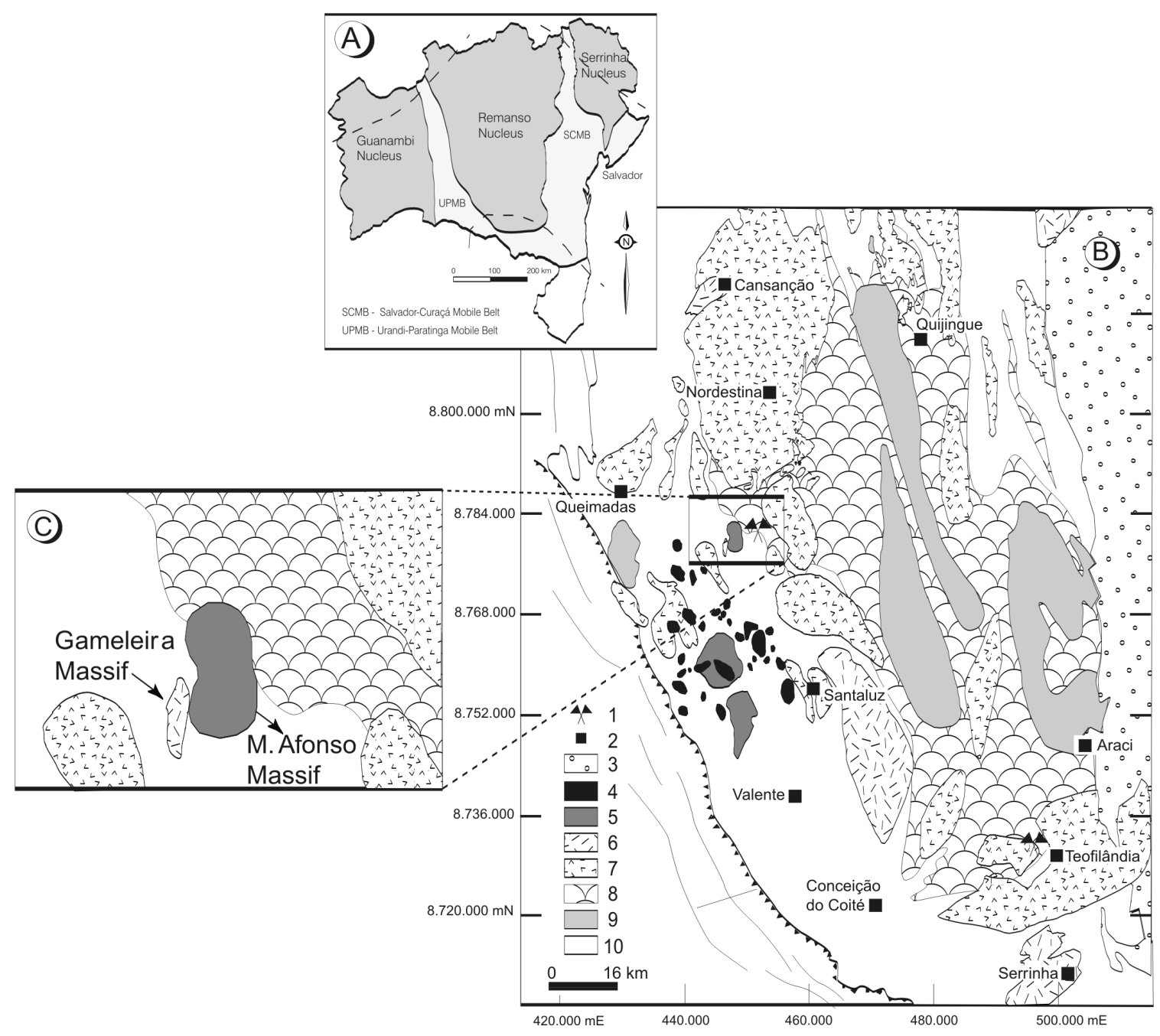

Figure 1 - (A) Mascarenhas (1979) tectonic model to Paleoproterozoic in Bahia. (B) Simplified geological map of the southern part of the Serrinha Nucleus with the proposal of Rios (2002) for the subdivision of granitic rocks. Legend: 1. Gold Mineralizations; 2. City; 3. Paleoproterozoic Potassic Granites; 4. Paleoproterozoic Ultrapotassic Syenites and Lamprophyres; 5. Paleoproterozoic Shoshonitic Monzonites; 6. Paleoproterozoic Calc-alkaline Granites; 7. Rio Itapicuru Greenstone Belt; 8. Archaean TTG domes; 9. Archaean gneissic basement. (C) Detail of a portion of Figure $1 B$ showing the Gameleira and Morro do Afonso massifs.

phibole and apatite, constituting the near-liquidus paragenesis, and feldspars restricted to the groundmass, is a typical feature described in lamprophyres (Le Maitre et al. 1989).

PETROGENESIS AND FINAL REMARKS The chemical analyses listed in table 1 were accomplished in the Acme Analytical Laboratories Ltd. (Canada). Major elements were determined by CP OES. Trace and rare earth elements by ICP-MS. For comparison, in this table are also presented the ultrapotassic lamprophyres from Morro do Afonso Massif (Rios 2002).

The Gameleira diorites present low $\mathrm{SiO}_{2}$ contents (44-47 wt \%) total alkalis close to $3 \mathrm{wt} \%$ and $\mathrm{K}_{2} \mathrm{O} / \mathrm{Na}_{2} \mathrm{O}$ ratio around 2. In the TAS diagram (Fig. 2) these dykes plot in the silica-saturated alkaline field, according to Irvine \& Baragar (1971) criteria. The relation between $\mathrm{K}_{2} \mathrm{O}$ and $\mathrm{Na}_{2} \mathrm{O}$, according to the proposi- tion of Le Maitre et al. (1989), points to a primary alkaline magma with a dominant potassic character. The low $\mathrm{Al}_{2} \mathrm{O}_{3}$ contents $(<10 \mathrm{wt} \%)$ are not typical of the shoshonitic series (Morrison 1980), and, in the same way, $\mathrm{K}_{2} \mathrm{O}$ concentrations below $3 \mathrm{wt} \%$ are in disagreement with the ultrapotassic clan as proposed by Foley et al. (1987). In spite of the low $\mathrm{Al}_{2} \mathrm{O}_{3}$ concentrations, the meladiorites present some chemical characteristics similar to shoshonitic rocks clan, or potassic as frequently used (Morrison 1980). The very high amounts of $\mathrm{MgO}(>11 \mathrm{wt} \%)$ are diagnostic of the primary composition of such rocks. $\mathrm{P}_{2} \mathrm{O}_{5}$ is also extremely high (1.4 - $2.00 \mathrm{wt} \%$ ), whereas $\mathrm{TiO}_{2}$ present intermediate values (1 - $1.5 \mathrm{wt} \%)$. Some classification diagrams using trace elements were developed by Muller et al. (1992), and the Gameleira dykes plots in the field of typical shoshonitic rocks (Fig. 3), showing that such magmatism, in some aspects, have chemical composition close to the 
Table 1 - Representative chemical analysis from Gameleira meladiorites and Morro do Afonso lamprophyres (Rios 2002).

\begin{tabular}{|c|c|c|c|c|c|}
\hline \multirow[t]{2}{*}{ Sample } & $11 / 22 a$ & $11 / 22 b$ & $11 / 22 \mathrm{c}$ & 952 & 953 \\
\hline & Gameleira & Gameleira & Gameleira & M. Afonso & M. Afonso \\
\hline $\mathrm{SiO}_{2}$ & 46.62 & 47.96 & 44.93 & 50.9 & 52.00 \\
\hline $\mathrm{TiO}_{2}$ & 1.44 & 1.45 & 1.51 & 1.10 & 1.00 \\
\hline $\mathrm{Al}_{2} \mathrm{O}_{3}$ & 9.40 & 9.42 & 9.72 & 10.60 & 11.20 \\
\hline $\mathrm{Fe}_{2} \mathrm{O}_{3}$ & 11.07 & 10.03 & 11.59 & 3.60 & 4.00 \\
\hline $\mathrm{FeO}$ & n.d. & n.d. & n.d. & 5.70 & 4.70 \\
\hline $\mathrm{MnO}$ & 0.18 & 0.20 & 0.18 & 0.19 & 0.18 \\
\hline $\mathrm{MgO}$ & 11.22 & 12.02 & 11.42 & 7.70 & 6.80 \\
\hline $\mathrm{CaO}$ & 12.32 & 12.19 & 13.74 & 10.3 & 9.50 \\
\hline $\mathrm{Na}_{2} \mathrm{O}$ & 1.03 & 1.13 & 1.07 & 1.10 & 1.10 \\
\hline $\mathrm{K}_{2} \mathrm{O}$ & 2.16 & 2.20 & 1.75 & 4.10 & 4.90 \\
\hline $\mathrm{P}_{2} \mathrm{O}_{5}$ & 1.83 & 1.40 & 1.97 & 1.50 & 1.50 \\
\hline LOI & 2.00 & 1.20 & 1.10 & n.d. & n.d. \\
\hline Total & 99.27 & 99.2 & 98.98 & 96.79 & 96.88 \\
\hline $\mathrm{Ba}$ & 3497.00 & 4281.00 & 5399.00 & 5394.00 & 6105.00 \\
\hline $\mathrm{Rb}$ & 61.8 & 135.4 & 76.2 & 89.00 & 115.00 \\
\hline $\mathrm{Sr}$ & 800.1 & 633.6 & 894.6 & 1838.00 & 2112.00 \\
\hline Cs & 1.7 & 11.5 & 3.1 & 5.00 & 5.00 \\
\hline $\mathrm{Y}$ & 44.5 & 56.7 & 59.3 & 40.00 & 41.00 \\
\hline $\mathrm{Zr}$ & 410.1 & 339.9 & 523.6 & 352.00 & 333.00 \\
\hline $\mathrm{Nb}$ & 22.5 & 13.6 & 19.9 & 11.00 & 16.00 \\
\hline Th & 66.3 & 52.00 & 77.00 & 33.00 & 24.00 \\
\hline $\mathrm{Pb}$ & 18.00 & 12.00 & 17.8 & n.d. & n.d. \\
\hline $\mathrm{Ga}$ & 17.5 & 14.9 & 15.6 & 10.00 & 10.00 \\
\hline $\mathrm{Ni}$ & 94.00 & 126.00 & 101.00 & 86.00 & 70.00 \\
\hline V & 209.00 & 180.00 & 212.00 & 163.00 & 136.00 \\
\hline $\mathrm{Cr}$ & 567.00 & 821.00 & 643.00 & 209.00 & 191.00 \\
\hline $\mathrm{Hf}$ & 10.9 & 9.3 & 12.3 & 8.00 & 8.00 \\
\hline $\mathrm{Ta}$ & 0.8 & 0.8 & 1.00 & n.d. & n.d. \\
\hline $\mathrm{La}$ & 214.3 & 334.7 & 387.6 & 193.6 & 191.2 \\
\hline $\mathrm{Ce}$ & 554.3 & 667.9 & 821.1 & 405.00 & 424.3 \\
\hline $\operatorname{Pr}$ & 48.56 & 69.76 & 82.39 & n.d. & n.d. \\
\hline $\mathrm{Nd}$ & 186.8 & 268.00 & 311.7 & 185.5 & 237.1 \\
\hline $\mathrm{Sm}$ & 32.8 & 42.2 & 48.1 & 36.6 & 37.8 \\
\hline $\mathrm{Eu}$ & 7.91 & 9.41 & 10.84 & 6.7 & 6.5 \\
\hline $\mathrm{Gd}$ & 19.64 & 24.53 & 27.36 & 21.9 & 18.4 \\
\hline $\mathrm{Tb}$ & 2.27 & 2.75 & 3.09 & n.d. & n.d. \\
\hline Dy & 9.58 & 11.62 & 12.33 & 10.8 & 8.3 \\
\hline Но & 1.42 & 1.72 & 1.89 & 1.9 & 1.4 \\
\hline $\mathrm{Er}$ & 3.56 & 3.66 & 4.21 & $3, .7$ & 2.5 \\
\hline $\mathrm{Tm}$ & 0.46 & 0.53 & 0.55 & n.d. & n.d. \\
\hline $\mathrm{Yb}$ & 2.45 & 2.91 & 2.97 & 1.8 & 1.1 \\
\hline $\mathrm{Lu}$ & 0.42 & 0.41 & 0.44 & 0.15 & 0.12 \\
\hline
\end{tabular}




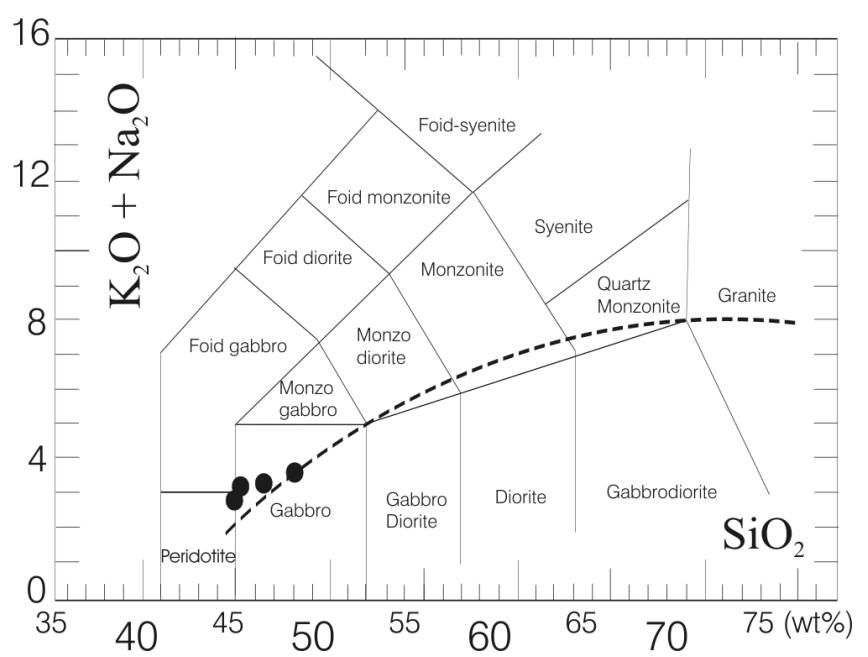

Figure 2 - Chemical classification and nomenclature of plutonic rocks using the total alkalis $\left(\mathrm{Na}, \mathrm{O}+\mathrm{K}_{2} \mathrm{O}\right)$ vs $\mathrm{SiO}_{2}$ (TAS) diagram of Middlemost (1994) applied to the Gameleira meladiorites.

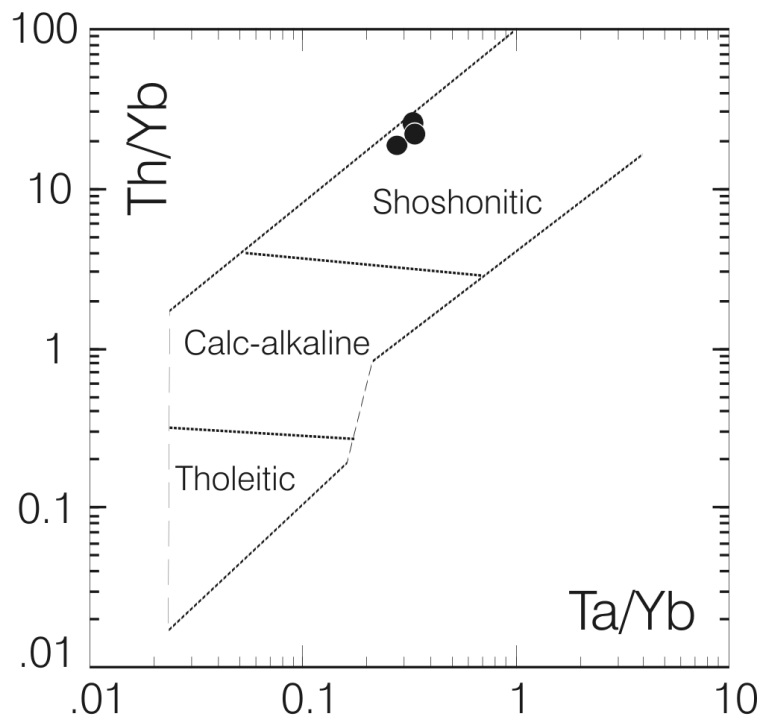

Figure 3 - Classificatory diagram of Muller et al. 1992 applied to the Gameleira meladiorites.

rocks of this series.

The primary character of the meladiorites is also corroborated by the trace element contents. High concentrations of $\mathrm{Cr}(>500 \mathrm{ppm})$ and moderate to low of $\mathrm{Ni}(94-126 \mathrm{ppm})$ are in agreement with a mantle origin for this magma, relatively enriched in pyroxene and olivine-free. Enrichments in large ion litophiles elements as $\mathrm{Ba}$ and $\mathrm{Sr}$, with moderate amounts of $\mathrm{Rb}$ are characteristics of these diorites (Table 1). The high concentrations of high field strengths elements (HFSE) typical in within-plate alkaline rocks are not observed, and the Gameleira meladiorites have moderate amounts of $\mathrm{Y}$ and $\mathrm{Zr}$, and low $\mathrm{Hf}, \mathrm{Nb}$ and $\mathrm{Ta}$. Relatively low contents of HFSE in potassic and ultrapotassic magma- tism have been associated with a metasomatic mantlesource in subduction-related settings (e.g. Peccerillo 1985, Foley \& Peccerillo 1992).

$(\mathrm{La} / \mathrm{Yb})_{\mathrm{N}}$ values, using the $\mathrm{C} 1$-chondritic values of Evensen et al. (1980), between 63 and 93 show the strong relative enrichment of LREE. High absolute concentrations of LREE are also verified; cerium reaches up to $821 \mathrm{ppm}$ (Table 1). Similar high amounts of LREE are observed in typical ultrapotassic rocks with within-plate (i.e. lamproites) and collisional (i.e. minettes) signature (Foley 1992, Gibson et al. 1992), and are therefore correlated with the metasomatic process, and not necessarily with the tectonic setting. REE patterns of the diorites do not exhibit $\mathrm{Eu}$ anomalies.

In figure 4, spidergrams of the Gameleira meladiorites normalized to the primitive mantle values (Sun \& McDonough 1995) are presented. Patterns show strong enrichment in LILE, except Rb, and LRE elements, with fractionation of HREE. Notable depletions are observed in $\mathrm{Nb}, \mathrm{Ta}$, and moderate for Sr. Similar patterns have commonly been associated to subduction-related magmatism, and in this case with intense metasomatic processes associated to the mantle-source as deduced from LILE and LREE enrichments. Morro do Afonso lamprophyres are plotted for comparison. The geochemical patterns of both meladiorites and lamprophyres are quite similar, indicating few differences between the sources.

Morro do Afonso lamprophyres have lower concentrations of $\mathrm{MgO}$ (6.8 to 7.7 wt.\%) and $\mathrm{P}_{2} \mathrm{O}_{5}(1.5$ wt. \%), and higher $\mathrm{K}_{2} \mathrm{O}$ (4.1 to 4.9 wt. $\left.\%\right), \mathrm{Al}_{2} \mathrm{O}_{3}{ }^{2}(10.6$ to 11.2 wt. \%), and $\mathrm{K}_{2} \mathrm{O} / \mathrm{Na}_{2} \mathrm{O}$ ratios (3 - 4) relative to the Gameleira meladiorites. According to several authors (Lloyd et al. 1985, Foley 1992, Foley \& Peccerillo 1992, Ionov et al. 1997, and references therein), pyroxene, apatite, phlogopite and amphibole are the usual phases found in upper mantle metasomatized regions. According to most petrologists, and as emphasized by Foley (1992), different proportions of these minerals, and to a lesser extent of typical mantle phases (garnet, olivine, spinel), participating in the melting processes may explain the diversity of alkaline potassium-enriched magmas. The comparison between Gameleira and Morro do Afonso primary magmas puts into evidence the presence of higher proportions of potassiumrich phases in the source of lamprophyres. The main carriers of potassium in the upper mantle are phlogopite and amphiboles (pargasite and richterite), and mica seems to be dominant in the metasomatic source from Morro do Afonso magmas, whereas the relatively lower amounts of potassium in the Gameleira meladiorites are probably due to higher proportions of amphibole in the source. This is enhanced by the lower $\mathrm{Al}_{2} \mathrm{O}_{3}$ of Gameleira meladiorites that is suggestive of lower amounts of phlogopite in the source. Apatite is an abundant phase in both sources, and clinopyroxene is dominant in the source of Gameleira meladiorites, as deduced from its higher MgO. Experimental data of Conceição \& Green (2000) have shown the importance of phlogopite and, mainly, pargasite melting in the upper-mantle to pro- 


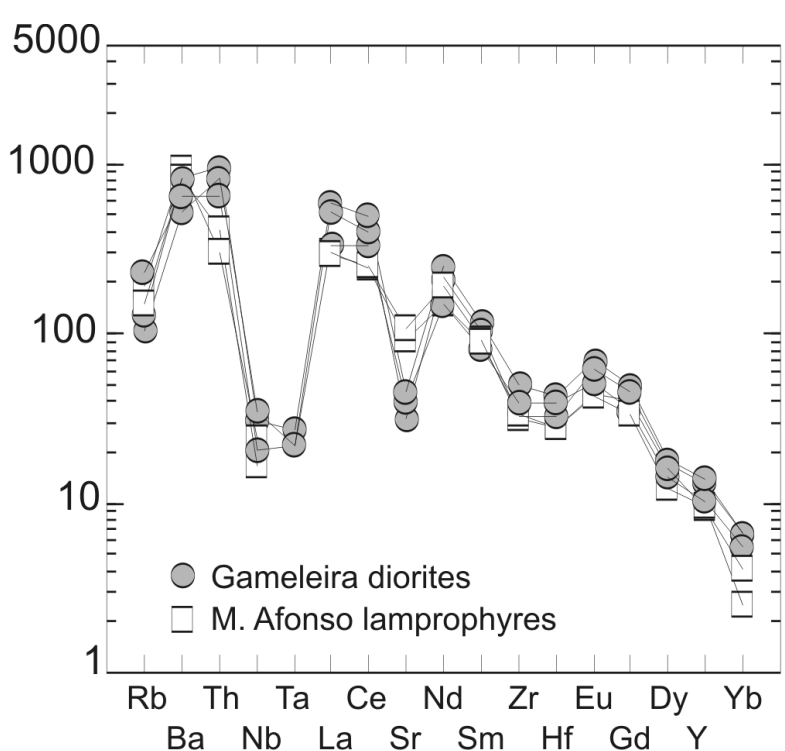

Figure 4 - Primitive mantle- normalized spider diagram (Sun \& McDonough 1995) applied to the Gameleira meladiorites.

duce potassic liquids. Different melting rate of the same source could be an alternative hypothesis.

The Cr concentrations of Gameleira meladiorites confirms high proportions of clinopyroxene at the source, more pronounced than those expected for the Morro do Afonso lamprophyres. Low to moderate Ni in both indicates an olivine-free source. Ba contents are similar in meladiorites and lamprophyres, probably concentrated by different K-rich phases (mica and amphibole) at the source of both magmatisms. O'Reilly \& Griffin (2000) suggest that apatite is the main carrier of LREE in the mantle. Slightly higher contents of $\mathrm{P}_{2} \mathrm{O}_{5}$ in the Gameleira magmas are in accordance with the higher concentrations of elements as $\mathrm{La}, \mathrm{Ce}$ and $\mathrm{Nd}$ when compared with the lamprophyres. Higher melting rate will be expected in the Gameleira meladiorites, which have higher concentrations of compatible elements. This will explain the lower amounts of elements as $\mathrm{K}$ and $\mathrm{Al}$, but not the concentrations of LREE and $\mathrm{P}$, higher in these rocks than in the ultrapotassic Morro do Afonso lamprophyres.

Gameleira meladiorites represent potassic liquids, with geochemical signature typically related to a mantle-source affected by metasomatic process related to by dehydration and/or melting of subductedslab. Very high concentrations of $\mathrm{MgO}, \mathrm{P}_{2} \mathrm{O}_{5}, \mathrm{Cr}, \mathrm{Ba}, \mathrm{Cs}$ and LREE are indicative of a mantle-source enriched in apatite and clinopyroxene, whereas the moderate amounts of $\mathrm{K}_{2} \mathrm{O}$ when compared with the contemporaneous ultrapotassic liquids from Morro do Afonso massif are suggestive of higher proportions of amphibole relative to mica. The comparison of the two primary magmatisms, forming bodies separated just by few kilometers on the field and probably contemporaneous, is a strong argument for mantle heterogeneity as the cause that originates different types of alkaline liquids. Experimental petrology data on phlogopite, richterite and pargasite (Sudo \& Tatsumi 1990, Luth 1997) have shown that temperature and pressure play an important role on the mantle stability of these phases. The identification of different mineral paragenesis in the source of ultrapotassic lamprophyres and potassic meladiorites from Serrinha Nucleus constitutes a good approach that can aid to better understand the tectonic evolution of this region.

Acknowledgments The authors thank to CAPES, MCT-CNPq, CNPq and FAPESB the financial support (Proc. N. 350349/2004-5). This is the scientific contribution number 217 from GPA-UFBA.

\section{References}

Bonin B. 1996. A-type granite ring complexes: mantle origin through crustal filters and the anorthosite-rapakivi magmatism connection In: D. Demaiffe (ed.) Petrology and Geochemistry of Magmatic Suites of Rocks in the Continental and Oceanic Crusts, ULB-MRAC, Bruxelles, p. 201-217.

Conceição R.V. \& Green T. 2000. Derivation of potassic (shoshonitic) magmas by decompression melting of phlogopite+pargasite lherzolite. Lithos, 72:209-229.

Corriveau L. \& Gorton M.P. 1993. Coexisting K-rich alkaline and shoshonitic magmatism of arc affinities in the proterozoic - a reassessment of syenitic stocks in the southwestern Grenville Province. Contrib. Mineral. Petrol., 113(2):262-279.

Evensen N.M., Hamilton P.J. \& O’Nions R. K. 1980. Rare earth abundance in chondritic meteorites. Geoch. Cosmoch. Acta, 42:1199-1212.

Foley S. 1992. Petrological characterization of the source components of potassic magmas: Geochemical and ex- perimental constraints. Lithos, 28:187-204.

Foley S.F. \& Peccerillo A. 1992. Potassic and ultrapotassic magmas and their origin. Lithos, 28:181-185.

Foley S.F., Venturelli G., Green D.H. \& Toscani L. 1987. The ultrapotassic rocks: Characteristics, Classification, and Constraints for petrogenetic models. Earth-Sci. Rev., 24:81-134.

Gibson A.S., Thompson R.N., Leat P.T., Morrison M.A., Hendry G.L., Dickin A.P. \& Mitchell J.G. 1992. Ultrapotassic magmas along the flanks of the Oligo-Miocene Rio Grande Rift, USA: Monitors of the zone of lithospheric mantle extension and thinning beneath a continental rift. J. Petrol., 34:87-228.

Ionov D.A., Griffin W.L. \& O'Reilly S.Y. 1997. Volatilebearing minerals and lithophile trace elements in the upper mantle. Chem. Geol., 141:153-184.

Irvine T.N. \& Baragar, W.R.A. 1971. A guide to the chemical classification of the common volcanic rocks. Can. J. Earth Sci., 8:523-548. 
Lameyre J. \& Bowden P. 1982. Plutonic rock types series - discrimination of various granitoid series and related rocks. J. Volc. Geoth. Res., 14:169-186.

Leat P.T., Thompson R.N., Morrison M.A., Hendry G.L. \& Dickin A.P. 1988. Silicic magmas derived by fractional crystallization from miocene minette, Elkhead mountains, Colorado. Min. Mag., 52:577-585.

Le Maitre R.W. (Ed.), Bateman P., Dubek A., Keller J., Lameyre J., Le Bas M.J., Sabine P.A., Schimid R., Sorensen H., Streckeisen A., Wooley A.R. \& Zanettin B. 1989. A Classification of Igneous Rocks and Glossary of Terms: Recommendations of the International Union of Geological Sciences Subcommission on the Systematics of Igneous Rocks. Londres, Blackwell, Oxford, UK, $193 \mathrm{p}$.

Loyd F.E., Arima M. \& Edgar A.D. 1985. Partial melting of a phlogopite cliopyroxenite nodule from south-west Uganda: an experimental study bearing on the origin of highly potassic continental rift volcanics. Contrib. Mineral. Petrol., 91:321-329.

Luth R.W. 1997. Experimental study of the system phlogopite-diopside from 3.5 to $17 \mathrm{GPa}$. Am. Mineral., 82: 1198-1209.

Mascarenhas J.F. 1979. Evolução geotectônica do Pré-Cambriano do Estado da Bahia. Geologia e Recursos Minerais do Estado da Bahia. Textos Básicos. Secretaria de Minas e Energia, Salvador, v.2, p. 57-165.

Middlemost E.A.K. 1994. Naming materials in the magma/ igneous rock system. Earth-Sci. Review, 37:215-224.

Morrison G.W. 1980. Characteristics and tectonic settings of the shoshonite rock association. Lithos, 13:97-108.

Muller D., Rock N.M.S. \& Groves D.I. 1992. Geochemical discrimination between shoshonitic and potassic volcanic rocks in different tectonic settings. A pilot study. Min. Petrol., 46:259-289.

O'Reilly S.Y. \& Griffin W.L. 2000. Apatite in the mantle: implications for metasomatic processes and high heat production in Phanerozoic mantle. Lithos, 53:217-232.

Peccerillo A. 1985. Roman comagmatic province (central Italy): evidence for subduction-related magmas. Earth and Plan. Sci. Lett., 95:53-72.
Plá Cid J., Bitencourt M.F., Nardi L.V.S., Conceicão H. \& Bonin B. 2000. Paleoproterozoic Anorogenic and Lateorogenic Alkaline Granitic Magmatism from Northeast Brazil. Precambrian Res., 104:47-75.

Plá Cid J., Rios D.C. \& Conceição H. 2006. Petrogenesis of mica-amphibole-bearing lamprophyres associated with the Paleoproterozoic Morro do Afonso syenite intrusion, eastern Brazil. J. South Am. Earth Sci., 22:98-115.

Ringwood A.E. 1990. Slab-mantle interactions. 3. Petrogenesis of intraplate magmas and structure of the upper mantle. Chem. Geol., 82:187-207.

Rios D.C. 2002. Granitogênese no núcleo Serrinha, Bahia, Brasil: Geocronologia e Liteogeoquímica. Tese de Doutorado, Instituto de Geociências, Universidade Federal da Bahia, 239 p.

Rosa M.L.S., Conceição H., Oberli F., Meier M., Martin H., Barreto Santos E., Paim M.M., Alves Silva F.C. \& Leal L.R.B. 2000. Geochronology (U-Pb/Pb-Pb) and isotopic signature (R-Sr/Sm-Nd) of the Palaoeproterozoic Guanambi batolith, southwestern Bahia State (NE Brazil). Rio de Janeiro, Rev. Bras. Geoc., 30(1):62-65.

Silva M.G. 1987. Petrologie, Geochemie und tektonische Entwicklung eines proterozoischen Grunsteingurtels: Rio Itapicuru, Bahia, Brasilien. Doktorarbeit, Universitaet Freiburg, 180 p.

Sudo A. \& Tatsumi Y. 1990. Phlogopite and K-amphibole in the upper mantle: implication for magma genesis in subduction zones. Geophy. Res. Lett., 17:29-32.

Sun S.-S. \& McDonough W.F. 1995. The composition of the Earth. Chem. Geol., 120:223-253.

Thompson R.N. \& Fowler M.B. 1986. Subduction-related shoshonitic and ultrapotassic magmatism - a study of siluro-ordovician syenites from the Scottish Caledonides. Contrib. Mineral. Petrol., 94:507-522.

Whalen J.B., Currie K.L. \& Chappell B.W. 1987. A-type granites - Geochemical characteristics, discrimination and petrogenesis. Contrib. Mineral. Petrol., 95: 407419.

Manuscrito CSF-21

Submetido em 31 de maio de 2006 Aceito em 01 de março de 2007 